\title{
THE IMPORTANCE OF THE EUROPEAN HEALTH TOURISM FOR THE DEVELOPMENT OF ECONOMY OF WELLBEING
}

\author{
Todorka Kostadinova ${ }^{1}$ \\ Siyka Katsarova ${ }^{2}$
}

DOI: https://doi.org/10.31410/tmt.2019.527

\begin{abstract}
This chapter builds on knowledge about modern management tools and economy of tourism sector with focus on the health tourism and the importance of health tourism destinations for the customers, for the European tourism business and for the economy of wellbeing. The main goals of the authors are to present on the first place the important role of the Health tourism for Europe with two of its components: spa tourism (travel to spas combining medical and health components) and wellness tourism (aiming to enhance 'health'), as it has grown exponentially in the recent years and become increasingly relevant in many destinations. On the second place - to propose an algorithm for an integrated model of health tourism destination management by using modern management and marketing tools, including innovative internet platforms. On the third place - to mark the important steps to those European destinations with natural resources, historical traditions, educational potential and modern infrastructure (with focus on Bulgaria) for being recognized and positioned as a competitive European destination for health and spa tourism.

The authors' suggestions will allow upgrading and elevating the existing understanding for the benefits for the European citizens and for the European tourist destinations (incl. Bulgaria), as well as to an advanced understanding of the tourism mix and the role of the positive impact of health tourism in the tourism business in Europe generally, as well as for improving the health and economy of wellbeing.
\end{abstract}

Keywords: health tourism, wellness, spa, destination management, algorithm, innovative solutions, economy of wellbeing.

\section{INTRODUCTION}

The tourism industry is a key sector of the European economy, generating more than $10 \%$ of EU GDP and employing 9.7 million people and involving 1.8 million businesses (Mainil, Tomas et.al, 2017).

Tourism is not only a business. The visitor economy brings a quantity of social benefits for Europe: it often provides the first job opportunity for youngsters, helps fighting racism and regional disparities, connects people and their cultures, contribute to increased demand for local agricultural products, handicrafts and gastronomy. Undoubtedly, the travel and tourism industry play an important role in the global economy. Technology of artificial intelligence, 5G and Fin-tech advances, mobile payment, apps, tourism platforms and social media are overturning the consumption patterns and forms of traveling, leading to industrial transformation of tourism and hospitality. To promote sustainability of tourism will be the greatest challenge for the travel industry today and in the near future through various emerging tools and rapidly developing technology. Thanks to tourism, people are visiting new destinations, but authors think that when taking a decision, a healthy environment is gaining much more importance than the new

Medical University - Varna, 55 Marin Drinov St., 9002, Varna, Bulgaria

Medical University - Varna, Bulgaria, Department of Health Economics and Management; European Spas Association; Bulgarian Union of Balneology and Spa Tourism 
destination itself. Therefore, the tourism in the modern era combines knowledge with physical activities and recreation that successfully regenerate the human body and soul and prevent the development of health problems.

Health tourism is an emerging, global, complex and rapidly changing segment that needs to be managed with modern management tools in the present era. Health tourism comprises around $5 \%$ of general tourism in the EU28 and contributes approximately $0.3 \%$ to the EU economy. Health tourism has a much higher domestic share than general tourism does. Increasing the share of health tourism may reduce tourism seasonality, improve sustainability and labour quality, and may help to reduce health costs through prevention measures and decreased pharmaceutical consumption (Mainil,Tomas et.al, 2017).

Health tourism is increasing its role as a significant contributor to the development not only of regional but also national economies. Despite certain tendencies in preference for individual (personalized) tourism, it is expected that health tourism and health tourism destination will continue to increase its influence and take bigger part in the tourism- mix in the future.

In this regard it is very important for the managers and for the leaders to apply modern tools of management and marketing communication in the management of health tourism destination. Particular characteristics of the health tourism products are having an influence on the usage and effectiveness of traditional forms of marketing communication (advertising, exhibitions, etc.) during the presentation of a health tourism destination. At the same time, because of the globalization and the technological progress they require combination between classical tools and new modern trends of marketing communication.

\section{THE MEANING OF THE EUROPEAN HEALTH TOURISM - MODERN MANAGEMENT AND MARKETING TOOLS}

There are in Europe over 2000 medical spas and health resort destinations, meaning areas of confirmed therapeutic properties of the climate that may be a remedy to limit the negative influence of harmful phenomena on society. Based on the results of the international research studies and on our professional experience we can state that health tourism and especially medical spa and spa tourism can limit both the negative effects of pollution by engaging in tourism in natural areas and at the same time meet the demanding needs of the aging society to maintain good health for as long as possible. European health tourism is developing (European Spa Association, Tourism Manifesto, 2019). This includes the classical medical spa as well as the medical spa sector and the countless wellness offers. According to estimates from the European Spas Association the approximately 18,000 health and wellness tourism facilities in Europe generate a turnover of more than 45 billion euros. This means that European facilities are not only an essential part of the health service in their national markets and in Europe, but also important economic contributors and employees. In addition, many of these jobs are in structurally week regions - as is untouched nature and the distance to industrialized regions an essential feature of many spas and health resorts (European Spa Association, Tourism Manifesto, 2019)

The authors consider that Europe needs to pay tribute to the important role of the tourism for the health prevention and take care of informing as great number as possible of its citizens and visitors about the self-responsibility and the health prevention combined with using natural remedies based on mineral water, landscape and climate and act against bad health habits. They promote 
spa medicine as a curative and preventive approach using natural remedies, rehabilitation techniques and education in healthy lifestyle (European Spa Association, Tourism Manifesto, 2019).

Europe has the chance to maintain and to develop its long-standing health resort and balneotherapy culture (also as part of the European Heritage) and to align it within today's national medical systems and the European Union. To achieve that it's very important to create the best possible conditions to develop the analyses regarding the medical issues. The outcome of this work should be used as powerful tool to market and to promote the European spas philosophy and local natural resources. To communicate the unique value, proposition of the European spa medicine (balneotherapy) is needed to deal with common health problems linked with unhealthy lifestyle and linked with ageing of the population. Balneotherapy care in many European countries has a long spa tradition and it is an integral part of the health care system. Balneotherapy is provided only in spa facilities with medical background that are recognized by the state authorities. As such, it is part of the health care system and must abide by strict regulations. The local natural healing resources (natural healing water, peloids, climate conditions) have always been subject to scientific research. Based on the knowledge of scientists and medical professionals, the treatments of particular diseases have been observed, approved and recommended.

\subsection{Management of the key challenges in the European tourism industry}

We are convinced that the management of the key problems of the tourism industry as seasonality (seasonal employment) and over tourism (in some urban cities) can be managed through developing European health-tourism destinations. Key arguments from the side of the authors are that all governments and stake holders need to create more possibilities to manage and market the European health destinations as an innovative product. There are plenty of arguments and among them one very important is that prevention can reduce the cost of national health systems.

In addition, an increasing number of companies in the industry place particular emphasis on and financing corporate health care. It is necessary to highlight the need for primary prevention (lifestyle change) and recognition of the risk of major chronic diseases through multimodal, behavioural interventions, such as health education, physical activities under the control of qualified staff, healthy nutrition and nutrition habits and the impact of psychosocial factors. The 1,400 spas and health resorts in the EU countries are the ideal and efficient partners for such services with expertise, in a quiet location with good air quality, as well as for rehabilitation, to prevent chronic diseases and mental health and for the assistance of the elderly people ( Nenova, G.; P. Mancheva, Paraskeva; T. Kostadinova, K. Mihov, Kalin; Sv.Dobrilov, 2018), (Milkov, M.; Matev, L.; Gradanska, S.; Kostadinov, Y.; Pl.Roussev, Kostadinova, T.; Dimov, P., 2018). Prevention and use of natural remedies without side effects are investments for the future. The new facilities throughout Europe have many sports and recreational sports offers and at the same time negative figures (28\% of the population of the European Union aged 16 or older do not practice sports or do physical exercise regularly) can be improved by motivation to physical activities in spa and health resorts with great infrastructure (European Spa Association, Tourism Manifesto, 2019).

Social policies and public as well as private initiatives aimed at improving the general well-being of citizens also support travel for health purposes. National and regional policies often pave the way for domestic and /or international health tourism (investments, incentives or regulations), especially it is supported by a relevant organization - Ministry or specialized non-government organizations (NGOs) (The World Tourism Organization (UNWTO), European Travel Commission, 2019). 
In recent years two important studies on tourism at EU institutions have been completed. Both studies investigate the health tourism as the possible alternative to the problems of tourism in the EU (Mainil,T., E.Eijigelaar, K.Jeroen, J.Nawijn, P.Peeters, Research for TRAN Committee - Health tourism in the EU: a general investigation study, EU Parliament, Committee on Transport and Tourism, Brussels, 2017). These studies show some important findings:

- health tourism comprises around 5\% of general tourism in the EU28 and contributes approximately $0.3 \%$ to the EU economy;

- health tourism has a much higher domestic share than general tourism: thus, increasing the share of health tourism may reduce tourism seasonality, improve sustainability and labour quality, and may help to reduce health costs through prevention measures and decreased pharmaceutical consumption.

Unfortunately, the false statements and non-business claims are based on non-systematic collected data and the omissions of information from the companies in the health tourism industry. Therefore, we are convinced that it is important to review the sources and data and that the involvement of companies, tourism operators, health tourism providers and related professional associations can support the decision making and the development with realistic and reliable information.

In the European tourism strategy the European Commission sets the objective of improving the accessibility of tourism services to sensitize the interested parties to generate greater know-how on the demand and profiles of travellers with specific needs and to evaluate the economic impact of the age-friendly and patient-friendly tourism (Mainil,T., E.Eijigelaar, K.Jeroen, J.Nawijn, P.Peeters, 2017). Ageing is one of the greatest social and economic challenges facing the EU. People aged over 50 spend a quite large amount of money in tourism, and health tourism is a "niche" market, where age-friendly tourism should also look at. Those customers like who travel with companions, extend the visits to family and friends, are not interested in "all inclusive" packages. They like wellness, recreation and health related offers (rheumatism, balneotherapy, dermatology, etc.), and gastronomic tours. They are interested in history and commemorations. They prefer autumn and spring rather than high season, when longer stays can mitigate the feeling of loneliness and isolation, especially where the offer for health services is provided and represents an added value. Older adults can be tourists, but also guests: becoming actively involved in the set-up of a personalized offer for tourism among peers, which might become a new approach to set up the tourist offer.

\subsubsection{Possibilities for Bulgaria to be positioned as a health tourism and spa destination on the European market}

This part of the chapter refers to the great potential of Bulgaria based on its natural resources (mineral waters, peloides, climate), historical traditions since Thracians and Romans times. This resources and advantages need to be updated, adjusted and tailored to the business requirements, educational system and modern infrastructure in the field of health tourism to change its image as a budget mass holiday tourism destination with the intense promotion of health tourism. Bulgaria is known mainly as a mass summer holiday destination and partly as a winter ski holiday. It is correct to discuss also the access to health tourism with regard to the availability of flights and transport infrastructure in the country. Despite of the great natural resources, Bulgaria is not so great access point for people to travel for medical tourism, due to the not developed region and the seasonality of the most popular tourism destination - the Black sea Riviera. This is a result from the limited number of flights out of the main summer season. The lack of recognitions as a destination for health tourism is the biggest challenge that stays in front of 
the national authorities and stakeholders in Bulgaria - Ministry of Health, universities, national recognized NGOs, professional associations, experts etc.

When we compare Bulgaria to the leading countries, with long term traditions, in the health tourism - Germany, Hungary, Czech Republic, Slovakia, our country started to create its reputation as a whole-year destination for health tourism 10 years ago (after being approved as a member of the EU).

The authors consider that the first steps of the process of positioning Bulgaria as a four seasons health destination can be done in appropriate way using "know - how" and best practices of other European countries, sharing the same values and philosophy. The membership of Bulgarian in the European spa association family (2007) helps the country to create its own national standards that are already part of the legislation (Tourism Act, Regulation 2., 2016). It regulates the order and minimum requirements for construction, furnishing and equipment, servicing, services offered and professional and linguistic qualification of the personnel, which must be met by the Bulgarian „Medical SPA Center”, „SPA Center”, „Wellness Center” and „Thalassotherapy (Black Sea Riviera is the prerequisite in the legislation to be determined thalassotherapy centre separately). The process of creating the regulation and its adaptation to the rapidly developing spa tourism in Bulgaria took 6 years and was guided by the experts from the European spa association, supported by the expert from the Bulgarian Union of Balneology and spa tourism (BUBSPA), expert from the National association of the medical doctors specialized in physical and rehabilitation medicine, experts from the Medical university - Varna, experts from national Sport Academy, expert from the Ministry of health, experts from Ministry of Education and coordinated by the Ministry of tourism. Both authors of the current chapter took part of the process from the very beginning in 2009 - 2010 when the first meetings and discussions started. The regulation helps the country to create the first step of its plan to develop all year-round tourism based on the Spa and wellness tourism as part of the health tourism. The main focus is given to the prevention and the promotion health using the local natural healing resources. In the following 10 years until 2019 the Bulgarian health tourism product starts to be directed and prioritized in the two main components - spa tourism and wellness tourism. According to the official information of the Ministry of health in Bulgaria, at the end of November 2019 there are 128 certified centres in the country (26 Medical spas; 83 -spa centres and 19 - Wellness centres).

The third component - medical tourism is left for the second stage of the development of the plan of the Ministry of tourism. It is included in the National strategy for sustainable development of the tourism on the territory of Bulgaria (2014-2030) (Ministry of Tourism, 2014) where is written that with the new tourism act approved in 2013 new aims are put as priority:

- conditions for sustainable tourism development and a competitive national tourism product;

- creation of conditions for development of alternative types of tourism - health tourism (and its three main components: medical tourism - travel for the purpose of medical treatment, spa tourism - travel to spas combining medical and health components and wellness tourism- aiming to enhance 'health';

- introduction of synchronized criteria for performing tourist activities and providing tourist services;

- ensuring the protection of consumers of tourist services.

Authors consider that Bulgaria has all the evidence based conditions to manage its tourism in a direction that will solve the same challenges as the other seasonal tourist destinations, e.g. 
Macedonia (Petrevska, B., Br.Nikolovski, 2018). The experts from Macedonia present the level of seasonality in Macedonian tourism and strategies and policies for coping with it, as well as to develop Macedonia as a health tourism destination. The main goals in Macedonia are similar to Bulgaria - to use the natural resources, to reduce the seasonality or eliminate it, to develop national programs for health prevention with financial support for the medical spa services.

Very useful good practice in Hungary is the program "Cafeteria system". It supports the local tourism market with both benefits for the customers and the business. "Cafeteria" in Hungary is a specific form of flexible non-cash benefits some of which are subject to a preferential tax treatment. Cafeteria provides a "menu" of possible benefits from which employees can chose and whose total annual amount is limited by the employer. Cafeteria benefits are usually offered uniformly to all employees or to a group of employees and their amounts are not dependent on the employees' performance. The benefits included in the Cafeteria system, their annual taxation limits and the applicable taxes are subject to annual updates. Thus, employers keep continuously adapting their packages to optimize the available tax incentives. Medical screening, physical therapy and mental health services provided by the employer, are specified in the applicable law (Hungary TMF Group Study, 2015).

An example for innovative practice is the Program for corporate social responsibility in Bulgaria in cooperation with Germany. In a cooperation with the German-Bulgarian Chamber of industry and commerce (GBCIC), the Bulgarian Union of Balneology and spa tourism (BUBSPA) develops since February 2019 a program for social corporate responsibility called "Health prevention card". The program aims to stimulate business representatives in Bulgaria to invest in the health prevention of their employees, which will lead to an increase in working capacity and the implementation of a socially responsible policy. The experience of the other countries as Hungary, Slovakia, Germany, could contribute to the improvement of the legislation and the financial mechanisms in Bulgaria, so that the business companies can invest in the human capital and support the local health tourism.

Another very important result of the partnership between the Bulgarian Union for balneology and spa, the German - Bulgarian Chamber of industry and commerce, the Medical university Varna, the Ministries of Tourism, Ministry of health of Bulgaria and Germany is the inclusion of Bulgaria in the list of countries eligible for reimbursement of expenses and services in recognized and certified spa centres and medical centres for outpatient services.

Since September, 2019, with an official letter, the Federal Association of Health Insurance Funds (GKV Spitzenverband) accepts Bulgaria in the list of Member States of the European Community, Contracting Parties to the Agreement on the European Economic Area (EEA) and Switzerland, for which outpatient assistance services in recognized resorts (Article 23, paragraph 2 of the Social Code - SGB V) are eligible for reimbursement of expenses and services used in Bulgaria for preventive medicine (ambulant services).

\section{MANAGEMENT AND MARKETING MODERN TOOLS:}

Social policies and public as well as private initiatives aiming at the improvement of the general wellbeing of citizens support travelling for health purposes. National and regional policies and initiatives are often paving the way for domestic and/or international health tourism (e.g., investment, incentives or regulations), especially if supported and facilitated by a relevant organization. 
Distribution in health tourism is quite unique. In medical tourism, facilitators (and not traditional tour operators) play an important role. In spa and wellness tourism, small but rather specialized tour companies provide packaged services or operate 365-day destination strategies. Health tourism can also contribute to tourism dispersal, as many wellness and medical facilities can be located in city outskirts and rural areas.

Collaboration and partnerships are the key among the different stakeholders involved in the health tourism value chain: destinations, authorities, local communities, accommodation and transport, providers, facilitators. Health tourism can be better integrated into tourism policies overall. The successful public-private initiatives to promote health tourism put in place some of the leading health tourism destinations, and which can be considered as best practices, could be replicated in other countries. Co-operation in health tourism can also have a trickle-down effect on know-how and technological transfer. Finally, cooperation with international organizations concerned becomes essential. Destinations should pay attention to product-segment matrices and the design of innovative marketing strategies /including digital/ that can touch and help attracting traditional, but as well as new market segments such as the so called "silver generation" or "addicted to the technologies generation".

\subsection{Tools for health tourism destination management and marketing}

The main management tools are given in this subchapter.

3.1.1. Destination management is the coordinated management of all elements that make up a destination as a health tourism including the natural remedies, attractions, infrastructure, education - middle and high, amenities, access, marketing and pricing.

3.1.2. Using Analysis and Scientific Research. The purpose of destination analysis is to determine the pattern of the tourism and develop the health tourism in the country. Experts conduct scientific research at the destinations and contribute their findings which can be a great aid to develop destination as a health tourism by protecting the ecosystem of various places.

3.1.3. Monitoring the Destination - annual surveys of the natural resources, businesses, residents, foreign tourists, and domestic tourists, about their experience and expectations at the destination.

Based on the literature research and on the professional experience we propose an algorithm for destination management. The algorithm can be applied in the health, spa and wellness tourism. The algorithm consists of the following main steps:

Step 1. Develop a vision for the destination as a health tourist destination. A vision is an exciting picture of a destination's desired future. The vision is intended to motivate stakeholders to work together to achieve this future. Vision brings all the stakeholders together and creates an integrated vision of all the individual visions of the stakeholders.

Tourism visions describe the style of tourism the destination would like to be recognized as health tourism and the target market for the destination. 
The main questions connected with the vision that needs to be asked according to the authors are:

- What do you want to see happen at the destination, so it became all year round attractive for the customers?

- How much of what type of tourism development fits with your image of your destination's future, based on the traditions, and natural resources that are popular for the destination?

- Does the destination provide its own labour force in the field of health tourism or needs to be imported?

- Does the destination have a potential to develop health tourism - sustainable, eco-friendly form of tourism and increase the quality of the tourists that are visiting it/ here the authors meant countries with a reputation as an economical mass summer /winter holiday as Bulgaria.

After asking these questions, it is followed by destination-wide meeting, gathering the local responses, and drafting the vision as a mean to start the work of destination development.

Step 2. Set the goals for tourism development as a health tourism destination, meaning economic socio-cultural, and environmental goals. Goals are realistic, measurable targets for the destination's tourism vision as a whole year-round health destination. Touch goal goes hand in hand with the vision. (UNWTO) While setting the practical goals, the authors consider the following answers as crucial:

- Does the destination want to be positioned as a whole year-round destination?

- Does the destination want to attract tourists all year round?

- Does the destination want to combine nature with modern facilities in a favour of the human's health?

- How many inbound tourists does the destination want to attract?

- Does the destination want to offer not seasonable job, but all year-round job?

- How many jobs, for whom, at what pay scales?

- How many educated employees /specialists does the destination need?

- How many medical spa, spa \& wellness centres/hotels are too many?

- How many tourists are too many?

\section{Step 3. Establishing a Health Destination Management System.}

Destination managers have the responsibility of creating a Health Destination Management System (HDMS). A HDMS is a database for collecting, manipulating, and distributing the recorded information. It includes the following information:

- Supply inventory and performance of medical spa\& spa \& wellness hotels\& centres, tour operators, specialized e-platforms,

- Supply inventory and performance of medical spa centres and clinics facilitators, eplatforms;

- Events, festivals, sports activities;

- Visitor profiles;

- Resident survey findings;

- Social, economic, and environmental impacts. 
Step 4. Include, create and use Internet resources: create an Internet platform and market the Destination on the Internet. Use the Web site as a tool of promotion of health tourism - e-marketing communication.

In present times, people have indisputable accessibility to information on various websites. It is extremely important for each tourist destination to be seen on the internet. It is a platform easy to navigate, clear website with high quality photographs of the destination and simple yet exceptional content can market any tourist destination effectively. Specialized web site as a communication tool in Health tourism have advantage as the travellers can obtain information and compare costs and make reservation easily if online access in available.

- Digital e-distribution platforms in the health tourism.

An e-marketing platform provides immediate access to relevant information of greater variety.

E-marketing activities in the health tourism can be considered as a mean of introduction products or services from supplier/producer to the customer and using an internet as a mean of promotion and a sales channel.

- The world is getting "online."

Considering all this facts and characteristics of some traditional marketing communication tools like advertising, personal sale, lobby, participation in fairs and exhibitions, sponsoring, sales promotion and especially some new ones like direct marketing, digital e-platforms, specialized summits for health tourism, public relation, internet marketing could lead to successful marketing communication of the destination.

High competition between the players of the tourism market has contributed to the further expansion of the digital space. Tour operators, in spite of the developed agency network, have preoccupied themselves with the formation of their own channels for the promotion of tourist services - electronic Business to Customers /B2C/ platforms intended for online sale of medical tourist products directly to consumers, bypassing intermediaries. The authors give the following innovative e-platforms as a good example what the future marketing of the health destination needs to follow:

- "YouSpa.eu" and "Spafinder.com" are innovative e-platforms that support the customers to find and buy spa packages/treatments but first the platforms influence on the consumer opinion using internal blogs and system for evaluations of the quality of the services;

- "Treatment abroad": e-platform/database popular both for medical spa and medical tourism;

- "WhatClinic.com" is an online platform that connect the customer with the most suitable clinic for his /her problem, it is a kind of online advisor;

- "IVFbabble.com" is an innovative e-platform/ mixed with live chat /B2C/ aiming to inform and to support the customers with the newest in the reproductive medicine as well as to connect the customer and the clinics.

According to authors it is important to analyse connections between the marketing activities and the knowledge of the clients; identify marketing as a management tool and as a factor of success and competitiveness of a destination; identify and make explicit the use of tools and tools to support marketing decisions and identify trends in the marketing of health tourism, as well as identify the elements that make up a marketing plan for health tourist services and destinations. 
The Authors give the following two examples of specialized summits for health tourism in Europe, focused on the development of the European Health destinations.

- Health Tourism Industry Summit (HTI) - Brussels is the leading platform for doing health tourism business in Europe and the leading European event of its kind. It brings together top professionals and thought health tourism industry leaders from private and public sector, who aim to address key challenges and discuss upcoming developments in health tourism industry. HTI enables global stakeholders to stay on top of the trends, to exchange and grow their knowledge, and to establish profound industry network generating new business opportunities. HTI represents a source of education, information and business intelligence, at the same time serving other industries complementary to travel for care.

- ITB Berlin offers a platform for the medical tourism segment, which has become an important fast-growing market. The Medical Tourism Pavilion is focused on the medical service providers, hotels and destinations to present their products and services. The adjacent Presentation Hub invites visitors to follow presentations, workshops and discussions to find out more about the latest trends and developments in this growing market and to address the challenges and opportunities for Europe as a destination of health, proposing the steps and measures to be taken.

\section{Step 5. Use of the social media}

Social media is one of the fastest growing communication technologies in the Internet environment. Social media marketing refers to Internet-based online media in which individuals with common interests, goals, and practices are engaged in social interactions constructing personal profiles and sharing information and experiences. One of the most important functions of the social media is that it provides a Web-based application in which users can easily create and post a variety of content - based on his/her personal experience, feelings, understandings in the forms of texts, photos, videos, etc. Social media represents a variety of forms such as social networks (e.g., Facebook), video creating and sharing sites (e.g., YouTube), online communities, micro-blogging tools (e.g., Twitter), newsreaders (Google Reader), public Internet boards and forums, review/rating websites (e.g., Trip Advisor, Holliday Check), photo sharing sites (e.g., Flickr, Photobucket), blogs/moblogs and individual websites. There are many ways how the marketing specialist working in the sector of the health tourism due to changes in technical, social and economic area, use of the most appropriate tool of modern marketing communication.

From a general perspective, most marketer's belief that social engagement through marketing requires a high level of understanding of the goals of both the consumers and the destinations in creating a social media presence. What is rarely addressed is the fact that social media platforms provide a context for the new creation of brand identity and for both positive and negative expressions of brand involvement.

Social media creates a venue through which computer-based word-of-mouth communication can significantly influence the brand image. Because one consumer can reach hundreds if not thousands of followers in a single post, destinations must address their approaches to managing social networks before creating an online presence.

Step 6. Use the Word-of-mouth: Word-of-Mouth marketing is focused on inducing the effect of the oral spread of "advertising" between customers themselves. 


\section{Step 7. Create the Branding of a health tourist destination.}

Destination branding is nothing but describing the visitors' experience in terms of facilities, amenities, attractions, activities, and other resources for people to turn them into tourists.

A strong destination brand creates an image about the destination, modifies people' perception about a place, influences decision-making, and delivers a memorable experience.

Destination branding takes collective efforts to provide best customer experience. When talking about international customers it includes airline industry, accommodation services, excellent medical spa services and effective follow-up process from the tourist facility.

\section{Step 8. Assess the economic impacts of the tourism destinations developing health tourism as a priority.}

Tourism is not exclusively an economic phenomenon, it also involves social, cultural, economic and environmental aspects. Tourism development brings along both positive and negative consequences. People should take responsibility and take action to make tourism more sustainable and environmental friendly and to put priority on those tourist products, parts of the whole mix when developing a destination, that educate the customers/consumers - starting from the very young age - and that bring added value to the society, developing healthy habits, etc.

This part of the chapter is related to several economic aspect of health tourism. These aspects include seasonality, labour - including education - and environment.

Seasonality - in General tourism, seasonality is acknowledged as one of the 'burdens' hampering the economic competitiveness of tourism (European Commission, 2015). The question is whether health tourism is suffering from seasonality to the same extent or whether it could be part of the solution to this problem. The authors consider that through developing health tourism the health tourism destinations somehow reduce and spread of the seasonality.

Labour - just as in general tourism, health tourism is a labour-intensive form of tourism requiring a wide range of skills across tourism, hospitality, health, healing, fitness, sport and spirituality (Dvorak, Saari, Tuominen, 2014). 'Some spas are large employers, like a town with 7,500 inhabitants, of which 450 work at the spa facility'. According to experts, other sectors also benefit indirectly from spa guests: spa tourism in Germany for example may provide 350,000 working places, most of them indirect. A consequence of the labour intensity and relatively high level of skills required, could be that the spa \& wellness sector struggles to find enough employees, warned experts.

Environment - the relationship between health tourism and the environment is two-way: most health tourism depends very much on a clean environment, but at the same time it also has an impact on the environment due to the mobility involved and the facilities in often vulnerable landscapes and ecosystems. Specifically, wellness and spa tourism depend largely on high quality environment including clean water, clean air and an attractive ecosystem. 'Spas need to be in a green 
environment'. A clean environment is an important reason to travel to health and well-being destinations and features as a unique selling proposition that is mentioned as the second most important factor for choosing a destination, with diverse beauty and pampering treatments being the first (Dvorak et al., 2014). This means that all those involved in health tourism should take responsibility for sustainable development of the environment (Dvorak et al., 2014), but at the same time, for environmental quality, as well.

Health tourism could be connected to and described as green tourism: from the environmental point of view sustainability means minimizing any damage to the environment (flora, fauna, water, soils, energy use contamination, etc.), while trying to value the environment in a positive way through protection and conservation.

\section{CONCLUSION}

Based on our professional experience we opine that in the whole management process it is very important to evaluate the possibility and critical factors of usage of selected forms of modern tools of marketing communication, such as internet marketing, social media, mobile marketing and the world of "mouth marketing", so that bigger part of the customers could receive an awareness of the importance to aim a healthy lifestyle (prevention and prophylaxis) using the healing effect of the nature and the effective methods used in the European health tourism destination.

The successful direction for Europe, today and in the future, is to show that all national governments need to put more focus first on the role of the prevention of the European people, the education of the youth about the importance of the healthy living (combining sport, using natural remedies and healthy feeding) and the importance of the European health tourism product. The authors think that the existing data base and research need to be extended and upgraded. The professionals and the academic society are obliged to show arguments to the decision makers and to the citizens that the health tourism (spa and wellness tourism in concrete) is a form of sustainable tourism. In Spa tourism essential part of innovation is in the water supply management, maintain of the underground water reserves. A sustainable growth of tourism could be achieved also by investment in education and continuous professional training. Health tourism needs well educated managers and employees both in health care and in the tourism industry.

\section{REFERENCES}

Dvorak, D., Health and Well-being in tourism destination, Turku, 2014, http://julkaisut.turkuamk.fi/isbn9789522165404.pdf (accessed on 1.10.2019).

European Spa Association: Tourism Manifesto 2019, Brussels, https://www.europeanspas.eu/ contents/news, (accessed on 20.10.2019)

Mainil,T., E.Eijigelaar, K.Jeroen, J.Nawijn, P.Peeters, Research for TRAN Committee-Health tourism in the EU: a general investigation study, EU Parliament, Committee on Transport and Tourism, Brussels, 2017; https://www.worldcat.org/title/research-for-tran-committee-health-tourism-inthe-eu-a-general-investigation-study/oclc/993633429\#details-allauthors; (accessed on 1.11.2019)

Milkov, M.; Matev, L.; Gradanska, S.; Kostadinov, Y.; Roussev, Pl; Kostadinova, T.; Dimov, P., Management of obstructive sleep apnea in certain professional groups through screening programs, Известия на Съюза на учените - Варна, (Journal of Union of Scientists, Series: Medicine and Ecology, 2017;22(2):38-41. ISSN: 2603-4565 (accessed on 21.11.2019) 
Ministry of Tourism, Bulgaria: National strategy for sustainable development of the tourism on the territory of Bulgaria 2014-2030, Sofia, 2014, http://www.mi.government.bg/files/ useruploads/files/strategy-bulgaria-2030_25022014.pdf). (accessed on 18.10.2019)

Nenova, G.; P. Mancheva, Paraskeva; T. Kostadinova, K. Mihov, Kalin; Sv.Dobrilov, Mentoring in the Fields of Physiotherapy and Integrated Care, Journal of Imab. 2018; 24(1):1923-1927. ISSN: 1312-773X, https://www.journal-imab-bg.org/issues-2018/issue1/JofIMAB-201824-1p1923-1927.pdf (accessed on 1.10.2019)

Shivachev, Y.; D. Grozdeva, P. Mancheva, Paraskeva; Bogomilova, G. Nenova, T. Kostadinova, Multidisciplinary Cooperation Between Complementary and Conventional Medicine with Patient Suffering from Myofascial Pain Syndrome, Journal of Imab. 2018; 24(3):21252128. ISSN: 1312-773X, https://www.journal-imab-bg.org/issues-2018/issue3/vol24issue3p2125-2128.html, (accessed on 1.10.2019)

Petrevska, B., B. Nikolovski, The level of seasonality in Macedonian tourism and strategies and policies for coping with it, 3rd International Thematic Monograph, Thematic proceedings modern management tools and economy of tourism sector in presentera,2018,http:// www.udekom.org.rs/uploads/4/7/0/4/47046595/6_thematic_monograph_2018_final.pdf, (accessed on 18.11.2019)

Puetter, M., The impact of social Media on Consumer Buying attention, Journal of International Business Research and Marketing, Volume 3, issue 1, 2017.

Sarah, S., The Importance of Social Media and Digital Marketing to Attract Millennials Behavior as a Consumer, Journal of International Business Research and Marketing, Inovatus Services Ltd., vol. 4(2), pages 7-10, January., 2019 https://ideas.repec.org/a/mgs/jibrme/ v4y2019i2p7-10.html, (accessed on 1.10.2019).

Shmarkov M.S., Russian Federation Digital technologies in the organization and management of tourist organizations, 1st International Scientific Conference „Modern Management Trends and the Digital Economy: from Regional Development to Global Economic Growth" - MTDE 2019, Advances in Economics, Business and Management Research, volume 81 (accessed on 15.10.2019)

TMF Group Study: The Cafeteria in Hungary, Global Reach local knowledge, Budapest, 2015, www.tmf-group.com (accessed on 20.11.2019).

Tourism Act of Bulgaria, Regulation 2., 2016,

Vaijdova, L, Modern Marketing Communication in Tourism, Journal of International Business Research and Marketing, Inovatus Services Ltd., vol. 4(2), pages 20-23, January, 2019, https://ideas.repec.org/a/mgs/jibrme/v4y2019i2p20-23.html, (accessed on 8.10.2019).

World Tourism Organization (UNWTO) and European Travel Commission: Exploring Health Tourism, 2018, https://www.e-unwto.org/doi/book/10.18111/9789284420209, (accessed on 10.10.2019). 